\title{
Dynamics of Performance Measurement and Organisational Culture
}

Umit S Bititci, Kepa Mendibil, Sai Nudurupati, Patrizia Garengo \& Trevor Turner Centre for Strategic Manufacturing, DMEM University of Strathclyde, Glasgow, UK

\author{
Corresponding Author: \\ Professor Umit S Bititci \\ Centre for Strategic Manufacturing \\ University of Strathclyde \\ James Weir Building \\ 75 Montrose Street \\ Glasgow, G1 1XJ
}

\section{u.s.bititci@strath.ac.uk}

Tel: 01415482015

Fax: 01415520557

Umit Bititci is the Director of the Centre for Strategic Manufacturing and Professor of Technology and Enterprise Management at the University of Strathclyde, Glasgow.

Kepa Mendibil is a Lecturer in Operations Management at the Centre for Strategic Manufacturing, University of Strathclyde, Glasgow.

Trevor Turner is a Senior Research Fellow at the Centre for Strategic Manufacturing, University of Strathclyde, Glasgow.

Sai Nudurupati has recently completed his $\mathrm{PhD}$ at the Centre for Strategic Manufacturing and is currently working as a Research Associate at the Centre

Patrizia Garengo is a post-doc researcher at the University of Padua in Italy and spent six months at the Centre for Strategic Manufacturing during $2003 / 2004$. 


\section{Dynamics of Performance Measurement and Organisational Culture}

\section{Structured Abstract}

\section{Purpose of the paper}

This is a research paper that aims to model the dynamic relationship between performance measurement, management styles and organisational culture, in order to develop a better understanding of the causal linkages between these three areas.

\section{Methodology}

The related literature on performance measurement, management control systems and management information systems, in the context of organisational culture, is examined and a framework for mapping the interplay of the three areas is developed.

The research is based around five case studies where performance measurement systems were implemented in action research programmes, using identical implementation methods, by the same research team. The use of the performance measurement systems were then observed over a period of time in relation to the implementation lifecycle, changes to management style and organisational structure over time. The dynamic relationships were then mapped using the framework developed. Patterns were observed, which led to new insights.

\section{Findings}

Organisational culture and management style seem to be interdependent throughout the lifecycle of the performance measurement system. That is, management styles need to evolve as the maturity of the performance measurement system and the organisational culture evolves. A successfully implemented and used performance measurement system, through cultural change, leads to a more participative and consultative management style. Similarly, the correct use of performance measurement systems can encourage an achievement culture to emerge. All five cases suggested that an authoritative management style was essential at the start but this would change with the emerging culture.

\section{Limitations and Implications}

The research results are limited to five socially constructed case studies. Whilst these findings remain valid, they cannot be used for universal generalisations. In terms of modelling the organisational culture, the research focuses on the organisation as a whole and does not take into account the possible existence of sub-cultures within the organisation.

\section{Practical Implications}

A better understanding of management styles and organisational culture will allow practitioners to better assess the organisations' readiness to implement performance measurement systems. Similarly, the results provide guidance towards the management styles that would be appropriate when implementing performance measurement systems in different cultural settings.

\section{Originality}

The framework for modelling the dynamic relationship between performance measurement, management style and organisational culture, together with the findings, should provide useful insights and methods for future researchers in this area. 


\section{Dynamics of Performance Measurement and Organisational Culture}

\section{Introduction}

The past fifteen years have seen significant research and development in the field of performance measurement, with various models, frameworks and methodologies by practitioners, consultants and academics. Some of these models, such as the Balanced Scorecard and the Performance Prism, have enjoyed general acceptance by and popularity with these communities.

Business improvement approaches, such as Six Sigma (Pande and Holpp, 2004), Lean Enterprise (Womack and Jones, 2003) and Theory of Constraints (Dettmer, 1997), also communicated the need for using performance measures for driving and sustaining business improvement.

On the one hand, business improvement techniques, such as above, together with a vast number of performance measurement related publications (such as Hoque and James 2000; Davis and Albright 2004) suggest that businesses perform better if they are managed using formalised, balanced and integrated performance measures. On the other hand, emerging literature suggests that the use of performance measurement systems, such as the Balanced Scorecard, does not make any difference to the business performance (Neely et al, 2004; Ittner et al, 2003). Others suggest that the impact of performance measurement is contingent upon the way they are used (Braam and Nijssen, 2004). 
Over the past ten years the authors audited and implemented performance measurement systems to facilitate performance management ${ }^{1}$ in industrial organisations. These implementations were studied as longitudinal case studies. Despite the fact that the implementations were facilitated by the same people, using the same (or similar) approaches, tools, and techniques, in companies that operate in similar environments, some of these implementations were successes and some were considered to be failures. During these implementations, the authors observed that:

1. Organisational culture and management styles have an impact on how performance measurement systems are implemented and used, thus affecting their success or failure.

2. Performance measurement systems can affect management styles and, to a certain extent, organisational culture.

These observations, together with the mixed evidence and messages presented in the literature, led the authors to question the community's understanding of the interplay between performance measurement, organisational culture and management styles. Thus, a retrospective study was instituted to explore the dynamics and relationships between performance measurement, organisational

\footnotetext{
${ }^{1}$ In this context Bititci et al (1997) differentiates between the Performance Measurement System (PMS) and Performance Management. According to this, the PMS is the information system that is used by managers to facilitate performance management and Performance Management is the management processes and the behaviours management uses/adopts to manage the performance of an organisation.
} 
culture and management styles to answer the following specific questions, as illustrated in Figure 1.

1. How do organisational culture and management styles impact on the success or failure of performance measurement systems implementations?

2. How do performance measurement system implementations impact on organisational culture and management styles?

The objective of this paper is to report the results and findings of this research programme.

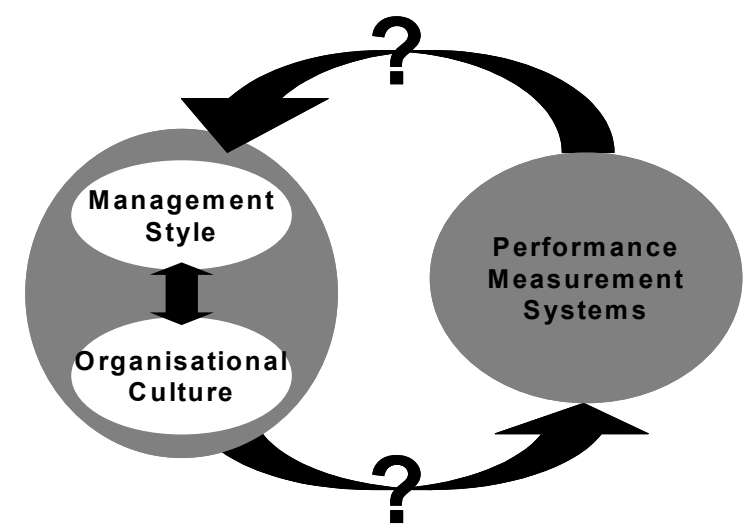

Figure 1. Questions on the interplay between performance measurement, management style and organisational culture.

\section{Methodology}

Action research (Eden and Huxham, 1996, Kaplan, 1998) forms the methodological basis of the research reported in this paper. Performance measurement systems were implemented in five different industrial companies as action research projects. The scope of these implementations included the overall performance measurement system covering all aspects of the business. Implementations followed concepts, 
tools and techniques previously reported in the performance measurement literature (see section titled Performance Measurement and Organisational Culture).

The five case studies were selected for this study from a larger pool of case studies, in order to maximise consistency and minimise variation. The five case studies were selected because the performance measurement implementation methodology used was identical across all five case studies, where the same research team played a role as educators, facilitators and advisors. The implementation methods, tools and techniques used followed the design, implement, use and review lifecycle that was supported by considerable education and training at all levels, as well as integrating personnel appraisal and review activities within the performance measurement framework.

The criteria used to assess the effectiveness or success of implementation for each case was based on Bourne et al (2002). That is, if the system was being used regularly to monitor performance and to make decisions and people had seen the value of using the system, the implementation was considered to be effective and successful.

In all five cases, access was gained through the Chief Executive or Managing Director of each company. The research team had unrestricted access to the organisation at all levels, as the projects were seen to be an integral part of their continuous improvement initiatives. The companies were using the research team as consultants to facilitate the implementation of a performance measurement system to facilitate continuous improvement. In the companies, cross-functional teams were formed to design, implement and facilitate the use and review of the performance measurement system. 
Organisational Culture and Management Style literature was reviewed and an appropriate profiling framework was selected to allow the researchers to profile the dynamics of organisational culture and management style throughout the implementations (see section on A Framework for Studying the Relationship between Organisational Culture, Management Style and Performance Measurement). The five cases were compared, and differences and patterns observed were explored to develop a better understanding of the interplay between organisational culture, management styles and performance measurement as depicted in Figure 1.

Although, in action research some may question the appropriateness of seeking patterns, these patterns were sought retrospectively to the action research after the outcome of the intervention was known. Thus, the nature of the patterns observed is valid as they relate to actual events and outcomes rather than interventions by the researchers. The events, outcomes and patterns were captured and mapped using a mapping technique especially devised for this study (see Figures 2 to 6 ).

Although this study was carried out retrospectively to the implementations, as explained above, the research team further engaged with the case study companies to validate and verify oral data, observations, interpretations and conclusions. This was achieved through the following process:

- The research team discussed each case study and created a map of factual events and mapped their data (including oral data, observations, documentation and research log) against these events, together with the hypothesised reasoning behind these observations. For example, on implementation of a particular performance measure (factual event) a change in management behaviour was 
observed (observation) which was possibly caused by a fear of exposure (hypothesis).

- These maps were then tested through discussions with individuals or groups of individuals to verify the validity of the observation and the hypothesis.

- These maps were amended to reflect the reality as agreed between the researchers and the individuals or groups of individuals concerned.

The resultant maps were used to conduct cross-case analysis to reach a better understanding of the interplay between performance measurement, management styles and organisational culture.

\section{Background Literature}

\section{Performance Measurement and Organisational Culture}

Towards the late 1980s and 1990s many academics had recognised the limitations of financial, internal and historically based performance measures (Skinner 1974, Hayes and Abernathy 1980, Goldratt and Cox 1986, Johnson and Kaplan 1987, Keegan et al 1989, Dixon et al 1990, Eccles 1991, Kaplan and Norton 1992, Neely et al 1995). Since then, there have been a number of frameworks and models developed for performance measurement and performance management (Bititci et al, 1997), such as Strategic Measurement and Reporting Technique (Cross and Lynch, 1988-1989), The Performance Measurement Matrix (Keegan et al, 1989), Results and Determinants Framework (Fitzgerald et al, 1991), Balanced Scorecard (Kaplan and Norton, 1992, 1996 \& 2001), Cambridge Performance Measurement Systems Design Process, (Neely et al, 1996), Integrated Performance Measurement System Reference Model (Bititci et al, 1997), Performance Prism (Neely and Adams, 2001), as well as various business excellence models, such as the European Business Excellence Model (EFQM, 1999). 
Other research programmes, and to a certain extent consultancy organisations, also developed approaches, procedures and guidelines for developing and designing effective performance measurement systems (Doumeingts et al, 1995, Krause, 1999). There have been several other initiatives for developing and defining performance measures for various business areas and processes, including performance measures for production planning and control (Kochhar et al, 1996), performance measures for the product development process (Oliver, 1996), Oliver Wright's ABCD check list for operational excellence (Anon, 2000). In addition to these, there are also tools and techniques developed to support performance measurement, such as Active Monitoring (Turner and Bititci, 1999), Quantitative Methods for PMS (Suwingnjo et al, 1997).

In 2001, Holloway (2001) identified that much of the research and development efforts have been focused on particular models and frameworks for performance measurement, but little was done to describe and analyse problems with the application of these models and frameworks. Similarly, Adair et al (2003) have concluded that the majority of the empirical research in performance measurement mostly comprises of case studies and surveys, with very progressive and longitudinal research programmes. Only a handful of researchers (Neely et al, 2000, Bourne and Neely 2000 and Bourne et al 2000, Nudurupati, 2003, Kennerley and Neely, 2003) used action research methods to investigate and study the life-cycle of performance measurement systems (i.e. design, implementation, use and review).

Bourne (2001), using systems dynamics and action research, identified two drivers and four blockers (Table 1) as key forces that affect success or failure of performance measurement implementations. Bourne (2001) defines a successful performance measurement implementation as a performance measurement system, 
which is used by the management team on a regular basis to discuss and manage business performance, related issues.

\begin{tabular}{|c|c|}
\hline Drivers & Blockers \\
\hline $\begin{array}{l}\text { - Top management commitment } \\
\text { - The perceived benefits arising from } \\
\text { designing, implementing and using } \\
\text { the performance measures }\end{array}$ & $\begin{array}{l}\text { - The time and effort required } \\
\text { - The difficulty of implementing the } \\
\text { measures caused by inappropriate } \\
\text { IT systems } \\
\text { - Resistance to performance } \\
\text { - Neasurement } \\
\text { New parent company initiatives }\end{array}$ \\
\hline
\end{tabular}

Table 1: Drivers and blockers of performance measurement implementations (Bourne, 2001).

Nudurupati (2003), using action research, facilitated the implementation and use of IT-supported performance measurement systems in manufacturing organisations. This research developed a causal relationship between infrastructural factors, structural factors, people factors and management and business implications of IT supported performance measurement systems. This research concluded that performance measurement systems, if appropriately designed, implemented, and used $^{2}$, would result in a more dynamic and pro-active management style, leading to improvements in business performance.

In the performance measurement literature there are many instances where authors have referred to the impact of organisational culture and management styles on success and failure of performance measurement systems implementations.

\footnotetext{
${ }^{2}$ See Nudurupati (2003) for full definition of appropriately designed, implemented and used performance measurement systems.
} 
Nudurupati (2003), to some extent, described how performance measurement can impact the way management behaves. Empirical studies (Bourne et al 2002) provide evidence that "paternalistic culture" can lead to a successful PMS implementation. Franco and Bourne (2003), as a prerequisite to success, emphasize the importance of organisational culture that does not punish people's errors and that encourages discussion and analysis around performance measures.

Similarly, research on organisational culture recognises that culture guides and shapes behaviours and attitudes of all employees (Hosftede, 1980; Handy, 1985; Schein, 1985; O'Reilly and Chatman, 1996; Burnes et al, 2003), which suggest that culture might also have an affect on business performance. In spite of a number of studies intending to understand the effect of organisational culture on business performance (Denison, 1990; Gordon and DiTomaso, 1992; Scott et al, 2003), recent studies suggest that this relationship is not yet well understood (Scott et al, 2003; Wang and Ahmed, 2003).

Although few researchers seem to have studied the implementation of performance measures and made observations with regards to the dynamic relationship between performance measurement, organisational culture and management styles, there seems to be limited empirically based research that has attempted specifically to understand the dyadic interplay between these variables. Similarly, research into organisational culture recognises that organisational culture has an impact on performance, but again this relationship is not well understood.

The performance measurement literature classifies a performance measurement system as a management information system, as well as a management control system (Bititci et al, 1997). In order to further understand the relationship between organisational culture and performance measurement, literature streams relating to 
management information systems and management control systems were also analysed in the context of organisational culture and management styles.

\section{Management Information Systems and Organisational Culture}

From the 1980s management information system literature started to pay increasing attention to soft aspects of information systems in organisations. In particular, authors such as Olson (1982), Pliskin et al (1993) and Claver et al (2001) studied the relationship between organisational culture and management information systems using different approaches.

Some studied organisational culture as the determining factor for acquiring and developing management information systems (Allard, 1998; Brown and Starkey, 1994; Gordon and Gordon, 1992; Katz and Townsend, 2000; Thompson and Wildavsky, 1986; Tolsby,1998), others studied how management information systems influence the organisational culture (Boland et al., 1994; Robey and Azevedo, 1994; Daily et al., 1996; Hibbard, 1998; Newman and Chaharbaghi, 1998; Olson, 1982). These studies suggest that there is indeed a dyadic relationship between management information systems and organisational culture.

Other research focuses on this dyadic relationship and identifies the need to understand organisational culture and to manipulate it to support the implementation of management information systems through cultural change programmes (Avison and Myers, 1995; Claver et al., 2001).

\section{Management Control Systems and Organisational Culture}

Research linking management control systems and culture seems to largely focus on National culture rather then organisational culture. Harrison and McKinnon (1999) and Chenhall (2003) independently reviewed the cross-cultural work in management 
control systems developed in the last 20 years. They found that these studies examine a different combination of cultural dimensions and different aspects of management control systems. They conclude that the findings are difficult to compare and generalization cannot be made. Harrison and McKinnon (1999) write that their studies examine a great variety of management control systems and organisational characteristics and there is little replication or confirmatory work on these characteristics. Chenhall (2003) concludes that it is possible to derive only one general proposition on the relationship between culture and management control systems, and that is "national culture is associated with the design of management control systems". This conclusion is also supported by Johnson and Gill (1993).

However, Baskerville (2003) criticises the use of Hofstede's (1980) five cultural dimensions (i.e. power distance, individualism, uncertainty avoidance, masculinity and confucian dynamism (Hofstede and Bond, 1988) in management control systems research as it is mainly focused on national culture. Similarly Mooraj et al (1999) identifies different types of culture that can affect performance measurement (national, occupational and organisational), but considers organisational culture to be the most relevant because it can override national and occupational differences (Collins and Porras, 1994).

\section{Conclusions}

Having had a brief look into the literature covering performance measurement, organisational culture, management control systems and management information systems, it can be concluded that:

- There is a dyadic relationship between performance measurement and organisational culture. However, none of the previous works attempt to develop a causal model between these two factors. 
- The previous works, although recognising the impact of organisational culture on performance measurement, do not explicitly state the role management styles play in setting and defining the organisational culture.

- The management information systems literature, although recognising the same dyadic relationship, suggest that organisational culture needs to be changed and adopted to meet the needs of the management information system. However, this view is not widely supported in the management control systems and performance measurement literature.

- The management control systems literature explicitly underlines the importance of organisational culture and management from the middle of the 1980s (Lebas and Weigenstein, 1986). However, these research results are still limited and an in-depth understanding of the causal relationships between the success of management control systems and organisational culture has not been achieved.

- In the performance measurement literature some papers are starting to refer to organisation culture as the key factor for successful implementation and use of performance measurement. Franco and Bourne (2003) describe corporate culture as one of the critical factors supporting the use of strategic performance measurement and they find two main approaches developed in the literature. The first underlines the need for an organisational culture supporting team-working, ownership of problems and risk-taking or entrepreneurship (Lingle and Schiemann, 1996, The Conference Board, 1999, AICPA, 2001, Johnston et al, 2002); the second emphasises the importance of organisational culture focusing on continuous improvement and the use of a strategic performance measurement system (Kaplan and Norton, 2001; Ho and McKay, 2002; De Waal, 2002).

Is seems that we (the performance measurement and management research community) understand that there is a dynamic relationship between performance 
measurement, organisational culture and management style. However, the exact nature of the interplay between these variables has not been explicitly studied and modelled, therefore, it is not well understood. Modelling this dynamic relationship would lead to a better understanding of the reasons why certain PMS initiatives fail while others succeed. It would also provide guidance to organisations embarking on PMS implementation projects. In order to model this dynamic relationship, a framework would first need to be created.

\section{A Framework for Studying the Relationship between Organisational Culture, Management Style and Performance Measurement}

In order to analyse the case studies and study the relationship between organisational culture, management style and performance measurement, the authors went back to the existing research on organisational culture and management styles and synthesised this knowledge into an appropriate framework. This section provides an overview into the literature behind the framework used. It is not intended as a comprehensive and critical review of the literature into culture, organisational behaviour, management styles and occupational psychology.

The leadership or management style is a key input to understanding the culture of an organisation (Schein, 1985; Pheysey, 1993; Cameron and Quinn, 1999). As a result, depending on the type of organisational culture, a particular management style will be more prominent and appropriate than others (Cameron and Quinn, 1999). Therefore, to avoid conflicts, it is important that there is alignment between the management style and the organisational culture.

Harrison (1987) suggests four types of organisational culture, which are based on Hofstede's work on national cultures (Hofstede, 1980). These types of organisational culture are: Role culture, Power culture, Achievement Culture and Support culture. In 
addition, Pheysey (1993) elegantly links research on management style with research on organisational culture, highlighting the types of management style that are more compatible with each type of organisational culture. These are as follows:

- Role culture: In the role culture, work is performed out of a respect for contractual obligations backed up by sanctions and personal loyalty towards the organisation or system (Handy, 1985). Here the power base of the leader is legitimacy and followers accord status out of respect for the office (Pheysey, 1993). The leader does what he/she is authorised to do. Leadership tends to be invisible, impersonal and even evasive. The leader practices 'selling', which is an intermediate position between telling and consulting. Quinn and McGrath's (1958) empirical expert type of leadership fits within the role culture. The leader is technically expert and well informed. He/she keeps track of all details and contributes expertise. His/her influence is based on information control, and as a result, documentation and information management are actively pursued (Cameron and Quinn, 1999). The empirical expert leader does what he or she is authorised to do (Pheysey, 1993). Another common management style to find in organisations with a role culture is Laissez-faire (Lippit and White, 1958), which means 'leave alone, leave others to do'. In this case, leadership is invisible, impersonal and even evasive.

- Power culture: In the power culture, work is performed out of hope of reward, fear of punishment or personal loyalty towards a powerful individual (Handy, 1985). The power base of the leader forces a degree of fear, deference or utility (Pheysey, 1993). Terms such as authoritative (Likert, 1967), autocratic (Lippit and White, 1958) and idealistic prime-mover (Quinn and McGrath, 1958) have been used to define the dominant leadership style commonly found within the 
power culture. Here the leader tells others what to do and he/she motivates employees by 'the carrot and the stick'.

- Achievement culture: In the achievement culture, work is performed out of satisfaction in the excellence of work and achievement and/or personal commitment to the task or goal (Handy, 1985). The power base of the leader is his/her expertise (i.e. knowledge and skills) and followers' accord status out of recognition of contribution (Pheysey, 1993). The leader is energised by competitive situations and actively pursues goals and targets. He/she continuously gives direction and encourages participation of employees. Appropriate management styles within the achievement culture are consultative (Likert, 1967) and rational achiever (Quinn and McGrath, 1958). Pheysey (1993) argue that these leaders believe that employees are already motivated but need encouragement to continuously achieve high performance.

- Support culture: In the support culture, work is performed out of enjoyment of the activity for its own sake and concern and respect for the needs and values of the other persons involved (Handy, 1985). Here leaders need to have personal charisma, which symbolises esteemed values. Followers accord status out of liking or identification (Pheysey, 1993). The leader in the support culture is people orientated, caring and empathic. He/she listens to the views of subordinates and takes them into account. His/her influence is based on getting people involved in the decision-making and on mutual respect and trust. This leader continuously manages conflict and seeks consensus and actively pursues participation, commitment, openness and morale (Cameron and Quinn, 1999). Terms such as participative (Likert, 1967), democratic (1958) and existential team-builder (Quinn and McGrath, 1958) have been used to describe this type of leadership style. 
Table 2 illustrates the framework that was used for analysing the case studies. This framework summarises the relationship between organisational culture and management style from previous research studies. The readers should note that the unit of analysis for this paper was the organisation as described rather then individual teams and groups within the organisation. The research was therefore interested in the dominant organisational-level culture and did not try to understand sub-cultures within the organisation. With regard to management styles, the research was predominantly interested in the management styles of the senior managers and the managers who were directly involved in, and affected by, the performance measurement projects. 


\begin{tabular}{|c|c|}
\hline Organisational Culture & Corresponding Management Style \\
\hline $\begin{array}{l}\text { Role Culture (logic orientated) } \\
\text { A bounded rational instrument for } \\
\text { the achievement of specified goals } \\
\text { of where people respond to role } \\
\text { (Harrison, 1987) }\end{array}$ & $\begin{array}{l}\text { A good boss is impersonal and correct, and avoids the } \\
\text { exercise of his authority for his own advantage. He } \\
\text { demands from subordinates only that which is required } \\
\text { by the formal system (Handy, 1985) } \\
\text { Predominant management styles: } \\
\text { - Empirical Expert (Quinn and McGrath, 1958) } \\
\text { - Laissez-faire (Lippit and White, 1958) }\end{array}$ \\
\hline $\begin{array}{l}\text { Achievement culture (mixed task } \\
\text { and people orientated) } \\
\text { The outcome of the interaction of } \\
\text { motivated people attempting to } \\
\text { resolve their own problems, and } \\
\text { satisfy their own needs and } \\
\text { expectation (Harrison, 1987) }\end{array}$ & $\begin{array}{l}\text { A good boss is egalitarian, and can be influenced in } \\
\text { matters concerning the task. He uses his authority to } \\
\text { obtain the resources needed to get on with the job } \\
\text { (Handy, 1985) } \\
\text { Predominant management styles: } \\
\text { - Consultative (Likert, 1967), } \\
\text { - Rational Achiever (Quinn and McGrath, 1958) }\end{array}$ \\
\hline $\begin{array}{l}\text { Power culture (output orientated) } \\
\text { A relatively bounded and stable } \\
\text { occurrence of social order based } \\
\text { on the habits of deference to } \\
\text { authority (Harrison, 1987) }\end{array}$ & $\begin{array}{l}\text { A good boss is strong, decisive, and firm but fair. He is } \\
\text { protective, generous and indulgent to loyal } \\
\text { subordinates (Handy, 1985) } \\
\text { Predominant management style: } \\
\text { - Authoritative (Likert, 1967), } \\
\text { - Autocratic (Lippit and White, 1958), } \\
\text { - Idealistic Prime-Mover (Quinn and McGrath, 1958) }\end{array}$ \\
\hline $\begin{array}{l}\text { Support culture (employee } \\
\text { orientated) } \\
\text { The mobilisation of bias through } \\
\text { personal relationships (Harrison, } \\
\text { 1987) }\end{array}$ & $\begin{array}{l}\text { A good boss is concerned and responsive to the } \\
\text { personal needs and values of others. He uses his } \\
\text { position to provide satisfying and growth-stimulating } \\
\text { work opportunities for subordinates (Handy, 1985) } \\
\text { Predominant management styles: } \\
\text { - Participative (Likert, 1967) } \\
\text { - Democratic (Lippit and White, 1958) } \\
\text { - Existential team-builder (Quinn and McGrath, 1958) }\end{array}$ \\
\hline
\end{tabular}

Table 2. Framework to understand the relationship between organisational culture and management style. 


\section{Case Studies}

In this section the framework outlined in the previous section is used to present five independent case studies on the implementation of performance measurement systems. For each case study the rationale, design, implementation and use of performance measurement are described in some detail with emphasis on organisational culture and management styles. Timeline maps are used to map the critical events and dynamics in organisational culture and management style. The section following the case studies presents a cross-case analysis leading to lessons and conclusions.

\section{Case A}

A is an independent profit centre within an international group which specialises in processing of metals from ingot to foil and associated products. At the time of the study, A employed approximately 420 people. The introduction of a performance measurement system was part of a larger programme to improve the capability of the Company to continually meet the EVA (Economic Value Add) targets required by the Group. The General Manager (GM1), who initiated the programme, had an autocratic management style and saw performance measurement as a means of measuring and monitoring the contribution of his managers in achieving their objectives (i.e. command and control). The two Area Managers (AM1 and AM2) provided monthly reports with performance measures for discussion at monthly Management Team meetings. It took a great deal of staff time to compile these reports and often the information was inaccurate and out of date. Meetings would degenerate into discussing the data accuracy and relevance rather than focus on improvement activity. Consequently, this initial attempt to instil a process of continuous improvement, based on performance measurement, was deemed to be a failure. 
The General Manager was promoted to a Group role and replaced by a new General Manager (GM2). The new General Manager was very IT literate and numerate and had a democratic management style. He had come from a part of the Group in which monthly reports were based on graphs and charts illustrating the process capability of the operations. He requested that all information be presented in the same format on an intranet based PMS that could be accessed at Management Team meetings. This was done and the information was used at meetings to identify processes that needed resources and focused continuous improvement $(\mathrm{Cl})$ team activity to improve process capability. The new General Manager insisted (Authoritative) that all mission critical performance information should be on the system and that nobody should be attending management meetings with other performance information. His view was that if it is of this importance, they should all see it on the shared system.

The Area Managers had to change their individual management styles to accommodate this new open, visual and consultative style adopted by the new General Manager. They needed to direct and encourage the continuous improvement teams in their own areas in a similar manner and participate in structured and systematic process improvements. Over an 18 month period, this factbased consultative management, focused on continuous improvement, changed the culture of the whole organisation from a support to an achievement culture. The net effect of this was that A became one of the best performing units within the Group.

\section{Case A: Synthesis}

Here the command and control oriented management style of the first general manager created a Power culture and his autocratic management style created a degree of fear and resentment in the organisation. In contrast, the democratic style of the second general manager came across as a shock to the organisation. For a while the organisation did not know how to cope with this new management style. However, through support and, where necessary, adoption of an authoritative management style, the second general manager and his managers were successful in implementing an integrated PMS that was used at all levels of the organisation in daily business.

The PMS, once in place and in use, supported by a consultative management style at all levels, led to greater buy-in at all levels. Its use to drive continuous improvement led to significant performance improvements. Elated with these levels of success, people wanted more of the same and gradually moved towards an achievement culture. 


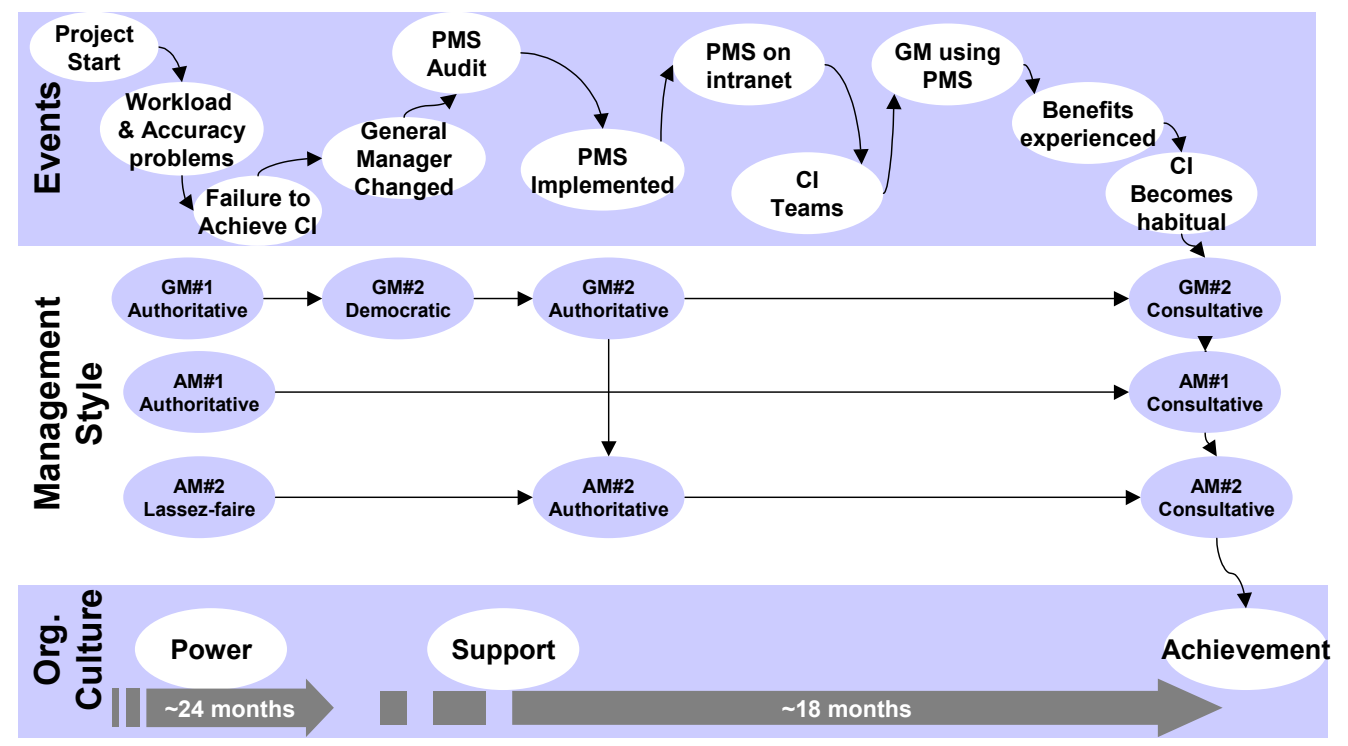

Figure 2. The interplay between performance measurement, organisational culture and management style in Case A.

\section{Case B}

B is a leading international spirit producer with 1200 employees. The Company is functionally organised with little communication between functions. Improvement projects launched by one department do not always tie in with initiatives in other departments. Predominantly, the organisation had a Power culture and the majority of decisions were based on experience rather than information.

The management team at $B$ decided to adopt and implement a performance measurement system using proprietary software (Quality Analyst) to gain better control of their operations (Figure 3). One of the researchers played a central role in assisting with the implementation of the performance measurement system. The key individuals involved in the project were the Operations Director (OD) and the Operations Manager (OM), both having an authoritative management style. The Quality Manager (QM) had a participative management style. 
In the first few months of the implementation, the PMS was used at management level with little usage at operational levels. However, over 2-3 months, the management realised the benefits and decided to deploy the system to operational levels. At this time the OD was driving the project using an authoritative approach and insisting that other managers use a similar approach (i.e. authoritative) to make staff use PMS in their daily business. This resulted in most managers and teamleaders in operations using the performance measurement system effectively as part of their daily business. Most performance related meetings and decisions were largely based on the information provided by the system. At this point in time, the performance measurement system implementation was considered to be a success.

However, six months later there were two events that changed the way the performance measurement system was seen and used within the organisation:

- $\quad$ The QM was promoted to Quality Director (QD) with plant wide responsibility for all performance related systems. In this new role the QD fell back to a participative management style. Under its newly found freedom, the quality department wanted to use a new automated data capturing system to record and classify the defects on-line and announced that the performance measurement systems would migrate to this new system. In contrast, the operations people, who had just got used to the performance measurement system already implemented, wished to use the existing system.

- Independent of this situation, the Parent Company announced that SAP enterprise systems would be standardised across the group and that all performance information would be reported using the SAPs management dashboard module as an integral part of the enterprise wide system. 
As one might imagine, these two independent events caused confusion and uncertainty within the organisation. As a consequence, the once successful performance measurement systems implementation failed.

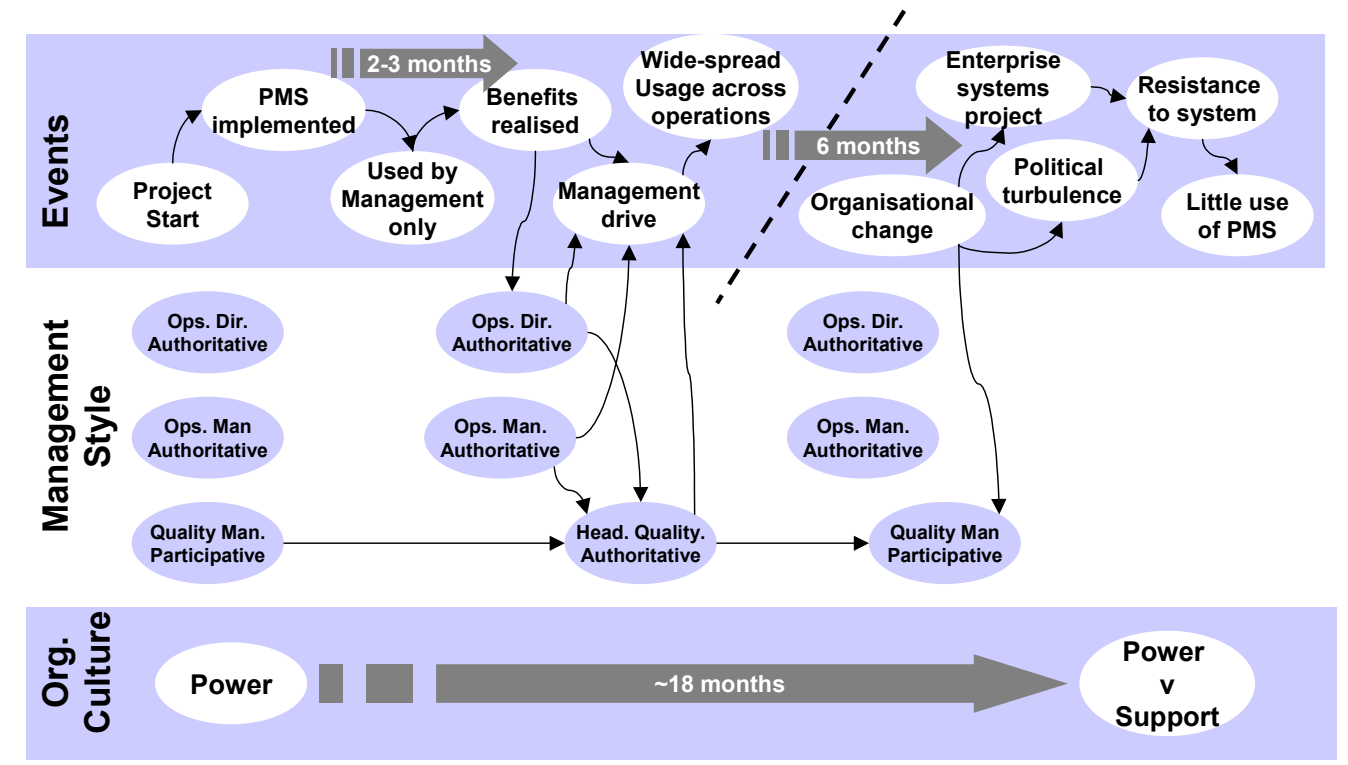

Figure 3. The interplay between performance measurement, organisational culture and management style in Case B. 


\section{Case C}

Case $\mathrm{C}$ is a well-known bottled water producer. In this Case the PMS project was initiated as a result of a visit by the management team to Case A. Following the visit, the management team was impressed with the quality of performance information and its use to drive continuous improvement. Consequently, a project was launched to create an intranet based PMS that would be visible to all and that would drive continuous improvement in all critical business areas.

The PMS system was designed using the combination of IPMS (Bititci et. al, 1997) and Balanced Scorecard (Kaplan and Norton, 1996). The PMS was implemented in the Company's enterprise systems by linking its database to various other sources of information and linking this database to an intranet site, thus allowing everybody within the organisation to access and view the performance information in near realtime.

During the initial twelve months of the implementation there was sporadic usage of the system. This was because of a very hands-off (Laissez-faire) management by the CEO and participative and consultative styles of the Operations Director and the Operations Manager, respectively. In short, despite the training provided, people did not know what to do with the system. Although it was regularly noted at the management meetings that the system was available and that it should be used, no one was owning and driving the use of the system.

Approximately twelve months after the initial start of the project, the Company implemented a new production line, which caused significant productivity problems, seriously affecting the cost base of the business. The CEO needed control, he wanted to know what was causing these problems and wanted to see some action to resolve the problems. Consultants were brought in to assist with this situation. The 
consultants recommended the use of daily flash-reports (one page daily performance reports). Ironically, all the required information was available on the existing PMS but was not being used. Subsequently, the CEO started to look at the performance information on a daily basis and ask questions about it to his subordinates every day. He wanted to know why the information was inaccurate, why the performance was not as planned and what were they doing to improve it. He insisted that (authoritative) the PMS system is used on a daily basis to communicate performance information between the CEO, the management team and the operational teams. This constant pressure by the CEO resulted in the Operations Director and Manager adopting a more authoritative style with their subordinates. Consequently, the accuracy of information on the system improved, people started to use the system to make decisions on what to improve and how. This resulted in people at operational and junior management levels asking for training in continuous improvement. This constant pressure over a period of twelve months, coupled with specific education and training on continuous improvement, kaizen and six-sigma resulted in wide usage of the PMS across all levels of the organisation, which resulted in significant improvements in productivity and business performance.

What is interesting is that, once the business performance stabilised, the management team fell back to their preferred management styles but the PMS system is still being used to drive continuous improvements through cross-functional teams. The organisation's culture seems to have shifted from needing to be told what to do (Power) to working together and by using facts systematically we can get things done (Achievement). 


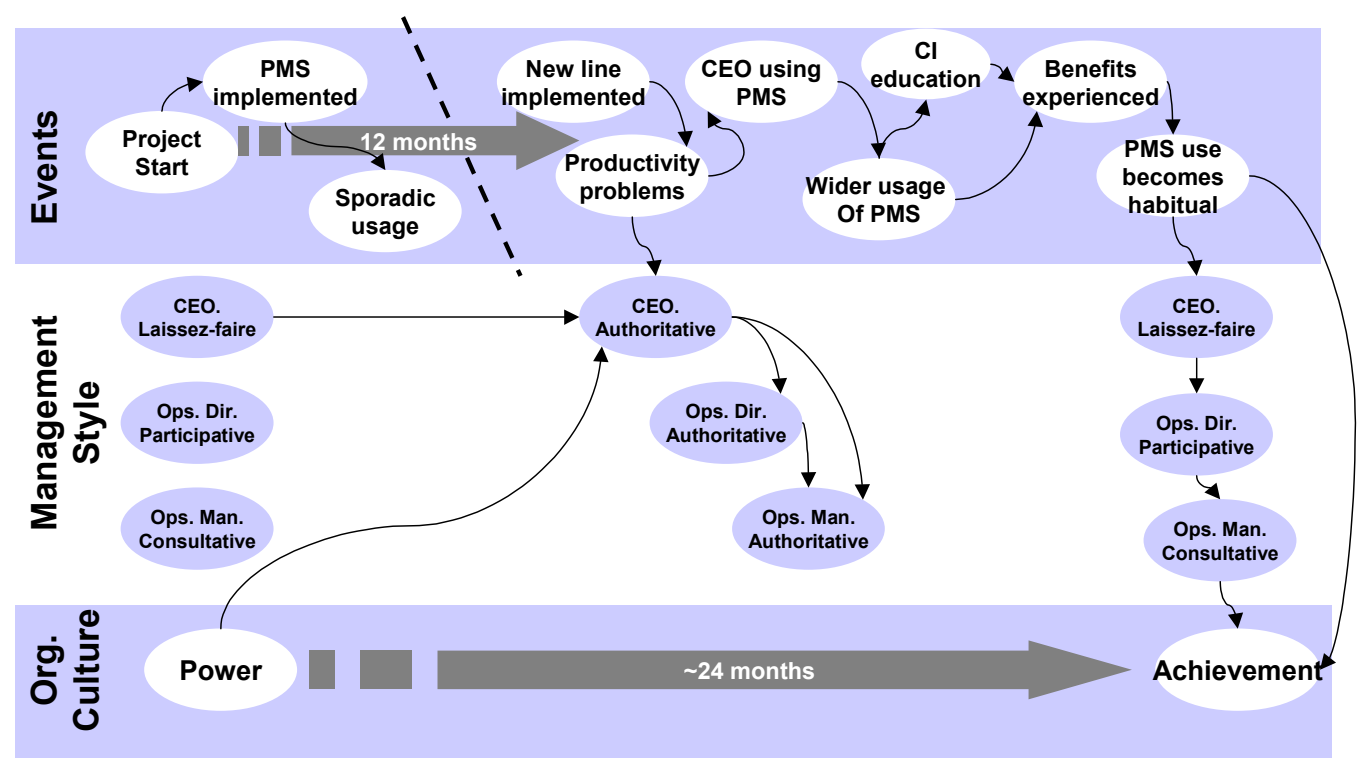

Figure 4. The interplay between performance measurement, organisational culture and management style in Case C.

believe that for the first time operational teams had the confidence in their ability to look at the performance information and use the tools and techniques given to them to drive improvements without being told what to do by the management. 


\section{Case D}

D is a subsidiary of a well-known transport and distribution company. It is privately owned and provides a variety of bonded warehousing services to the spirits and electronics markets. The Company had a predominantly paper based management systems, with the exception of accounts. This limited management's ability to control the business. Information had to be requested from different people who, in some cases, carried the information in their heads. The PMS project was initiated to provide the management and operational staff with factual performance information to allow them to make better strategic and operational decisions.

At the outset of the PMS project the organisation demonstrated a power culture. Although the managers often based their decision on their experience and what they were told by others, it was the Operations Director (OD) who made all the decisions and told others what they should do, because this was what was expected. In contrast to this power culture, the Managing Director (MD), who was planning to retire soon, left everyone to get on with it (laissez-faire) while the newly appointed OD and the Planning and Operations Manager (POM) liked involving everyone in the business (a participative management style).

The Company used the accounting systems together with proprietary process control software and Microsoft Access to develop a Company wide PMS. One of the researchers was engaged as a technical facilitator to assist with the development and implementation of the PMS.

Throughout the subsequent months, the use of the system was limited to the management team within the organisation, as the POM did not adjust his 
management style and did not drive the use of the PMS at operational levels. However, following a presentation to their largest customers and, triggered by the customer feedback, the OD realised that the PMS system could be used as a means of engaging the customer in the processes of the Company and its suppliers, as well as deriving and demonstrating continuous improvement across the supply chain. Having recognised the potential of the system, the OD started to drive its use throughout the organisation by insisting the system be used at all levels (i.e. an authoritative management style).

Shortly after realising that, by developing its supply chain management (SCM) capability and offering its customers an end-to-end SCM service, the Company embarked on a SCM systems project, by selecting and implementing a SCM system. The purpose behind this was to provide customers and suppliers with end-to-end visibility, including performance information. A Business Systems Manager (BSM) was recruited to project manage the implementation. The BSM, driven with very tight deadlines, adopted an authoritative management style and drove the use of the PMS at operational levels. 


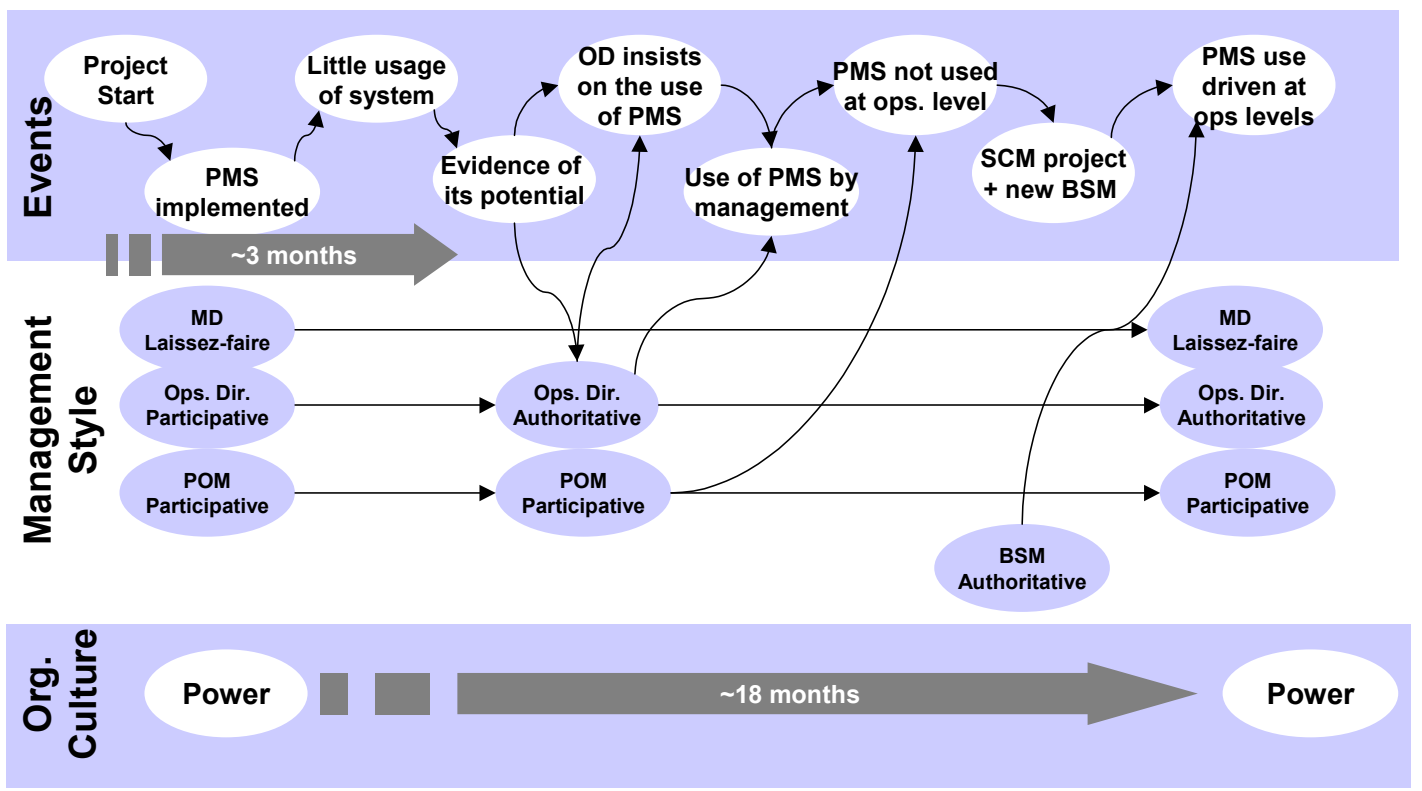

Figure 5. The interplay between performance measurement, organisational culture and management style in Case $D$.

rganisational culture will change to an achievement culture within 12 months - once the SCM project is completed and early benefits of the PMS are realised.

\section{Case E}

The Company manufactures and provides self-adhesive labels and flexible packaging solutions to a wide range of market sectors throughout the UK and Europe. The company had an intranet based information system that provided some data to managers and team leaders but was not available on the shop-floor. The 
information provided was in its raw form. Generally, users spent a lot of time getting the data and analysing it as best as they could with little direction from the management team.

The Company had a new management team. The Managing Director (MD) and the Finance Director (FD) both expected people to get on with their jobs (laissez-faire). In contrast the Operations Manager (OM) had a participative style with his subordinates but expected to be told what to do by his superiors. The Marketing Manager (MM) had a consultative style but also expected to be told what to do with his superiors. Power Culture was dominant across the organisation.

The management team wanted to gain greater control on the operations of the company in order to drive continuous improvements. Consequently, they decided to implement a PMS system across operational functions. One of the researchers acted as a facilitator to assist with the design, implementation and use of the PMS system.

The PMS was designed, implemented and used by the OM, team-leaders and other operational staff. The system relied on data from the existing systems of the Company. The MD did not show much interest in actually using the system himself, he expected people to just get on with it. Here, the support culture prevailed. For a while the PMS system was used but, without strong direction from the MD, the information generated was not acted upon. Within a few months people started to question the point of maintaining a system that was not being used for anything. Consequently, the usage of the system reduced.

About six months into the project a new continuous improvement initiative was launched, which led to the introduction of Overall Equipment Effectiveness (OEE) based performance measures. However, the data captured in the existing systems of 
the company was not able to support the new measures, which led to inconsistencies and arguments over OEE measures. This led to a loss of confidence in the PMS. The project was suspended until the Company updated its information system.

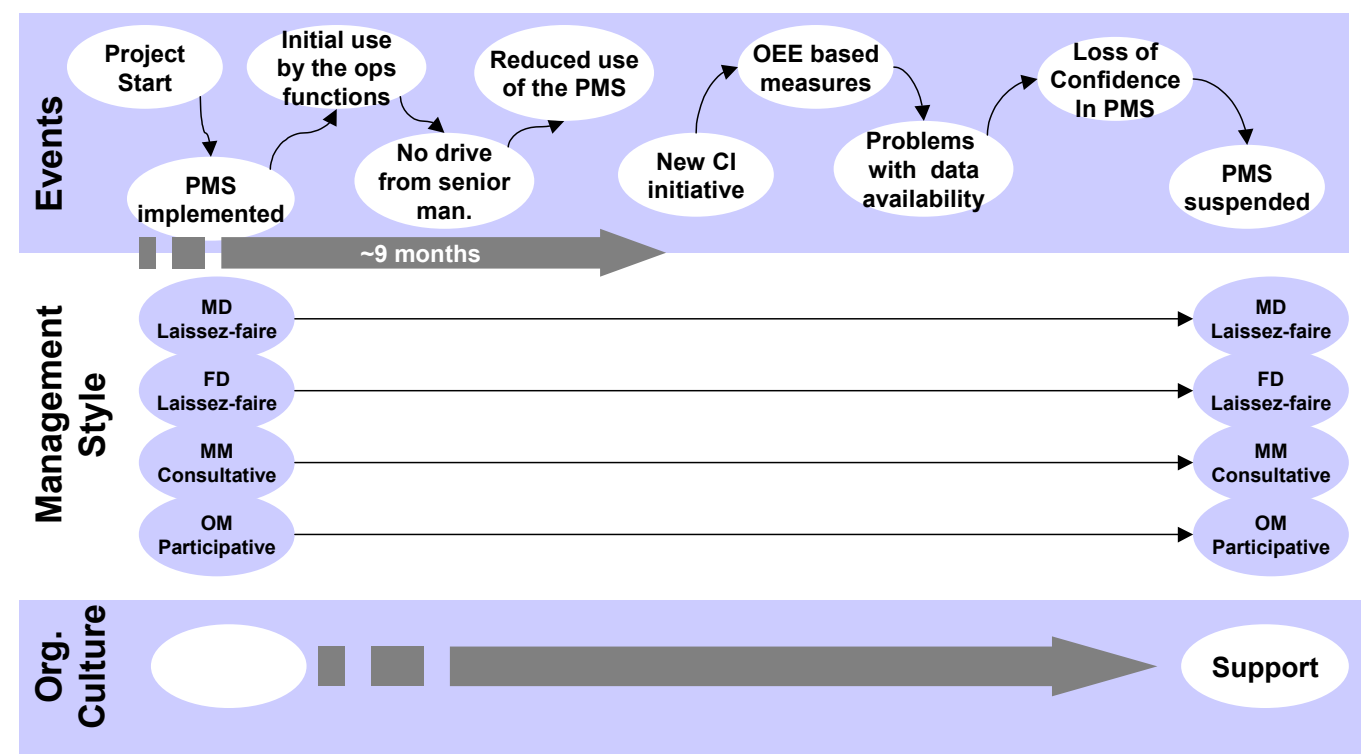

Figure 6 . The interplay between performance measurement, organisational culture and management style in Case $\mathrm{E}$.

cre

there

management style. This

techni

\section{Analysis and Discussion}

In this paper we presented five cases, which may be summarised as follows.

- Cases A and C have successfully implemented a performance measurement system and are using it to derive improvements in their businesses.

- Case B seems to have implemented a successful performance measurement system but a functional mind-set and lack of joined-up thinking resulted in a failed 
implementation. However, with the introduction of their new ERP system they may recover from this situation.

- Case D, similar to A and C, seems to have successfully implemented a working performance measurement system. However, at the time of writing it is too early to report on the business benefits and cultural change this had caused in the business.

- Case $E$ is a failure.

It seems that there is a pattern emerging across these five case studies with respect to the interplay between performance measurement, management styles and organisational culture. These patterns may be summarised as follows:

- Impact of Management Style on PMS: It seems that managing with performance measures is not a natural thing to do for these organisations. In all organisations that have successfully implemented a performance measurement system (Cases A, B, C and D), the driving senior manager(s) had to adopt an authoritative management style. Where use of the performance measurement system led to positive results (Cases $A$ and $C$ ), the use of the system was sustained and the managers were able to move back to their preferred management styles. Case E, which was an outright failure, together with experiences of other cases, (i.e. the first twelve months of Case $C$, and the first three months of Case D) suggests that an Authoritative management style is an essential requirement for successful implementation of performance measurement systems. However, an Authoritative management style is not essential in order to sustain the continuing use of the system once an Achievement culture is achieved. 
- Impact of Organisational Culture on PMS: By coincidence, it seems that all the case study companies demonstrated a Power culture at the starting point. The data emerging from the case studies suggest that the initial organisational culture does not have an impact on success or failure of performance measurement systems.

- Impact of PMS on Management Style: Cases A and C suggest that successfully implemented and used performance measurement systems leads to a more participative and consultative management style. This supports Nudurupati's (2003) earlier work, where he argues that a more participative and consultative management style is achieved due to improved visibility, reduced ambiguity and improved communications.

- Impact of PMS on Organisational Culture: Again based on Cases A and C and to a limited extent on $D$, it can be concluded that successful performance measurement systems lead to a change towards an achievement culture.

\section{Lessons and Conclusions}

The findings from the cases studies suggest that there is indeed interplay between organisational culture, management styles and performance measurement. In fact, this interplay is bi-directional, i.e. PMS can shape organisational culture and management style, and organisational culture and leadership style can affect the success of a PMS initiative.

It was evident from the case studies that if successfully implemented and used, performance measurement systems, through cultural change, lead to a more participative and consultative management style. Similarly, the use of performance 
measurement systems, to drive continuous improvement, can lead to significant performance improvements. Elated with success, organisational culture gradually moves towards an achievement culture. As all the case studies presented seemed to have started with a Power culture, we can conclude that authoritative style is an essential requirement when the organisation demonstrates a Power culture.

This interplay suggests that, in order to successfully implement PMS, companies need to review and adapt the organisational culture, management style and structure of the PMS in line with their specific needs. This conclusion challenges the view of Claver et al (2001) who claim that organisational culture should be modified to meet the needs of the PMS. We would argue that both culture and PMS should be adapted to the specific context of an organisation.

Performance measurement is a cross-functional issue. It, therefore, requires joinedup thinking at all levels of the organisation. A functional mind-set can seriously undermine the success of a performance measurement system. This fact was evident in Case B.

Finally, based on the observations from the case studies, we can conclude that managers do not readily change their management styles. External stimuli, including action researchers, play an important role in leading managers to change their management styles.

A key finding of the work presented in this paper is that organisational culture and management style seems to be interdependent throughout the lifecycle of the performance measurement system. That is, management styles need to evolve as the maturity of the performance measurement system and the organisational culture evolves (Figure 7). 


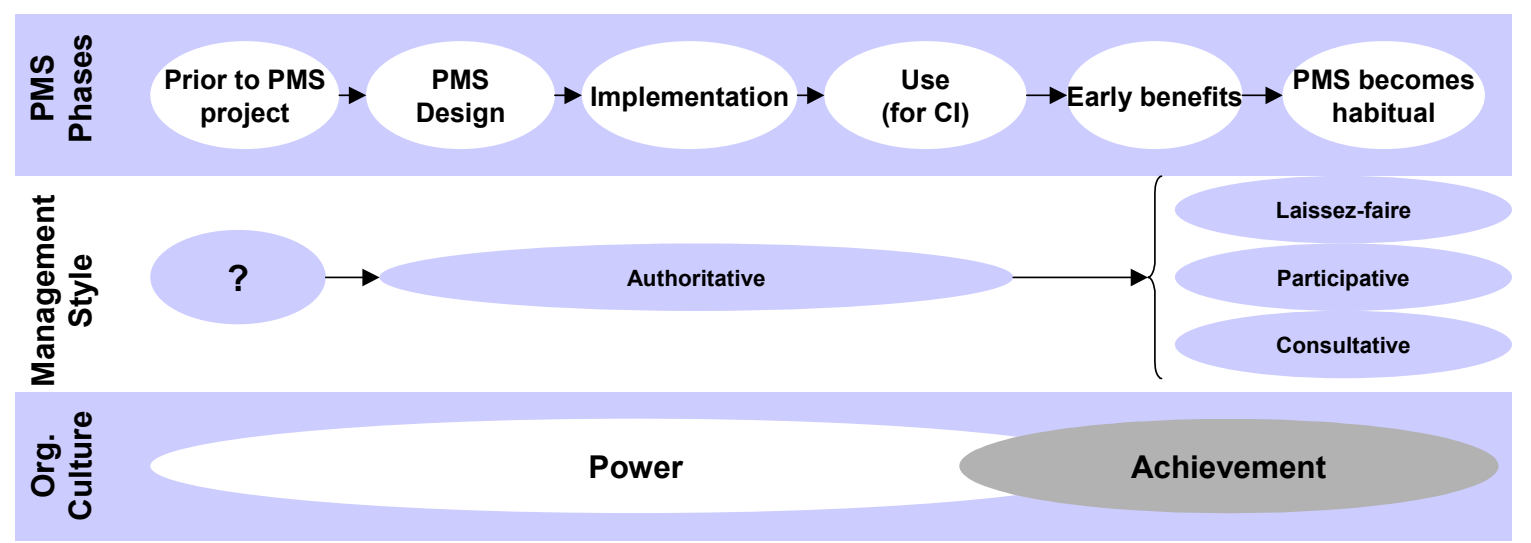

Figure 7. Interplay between phases of performance measurement, organisational culture and management style.

The primary limitations of this research are:

- The findings are based on only five case studies, thus only scratching the surface of the questions asked at the outset. In fact, all five organisations are from the manufacturing sector in the same country (UK).

- The selection criteria of the five cases (i.e. using the same approach) whilst minimising the effect of other factors on the results obtained, could result in a bias towards the implementation approach used.

A much broader study involving manufacturing service, as well as the public sector, and using a variety of implementation approaches, may reveal significantly more insights into the interplay between performance measurement and organisational culture. Therefore, more research is required to develop a robust understanding of the interplay between culture, management styles and performance measurement. 


\section{References}

Adair C. E., Simpson L., Birdsell J. M., Omelchuk K., Casebeer A. L., Gardiner H. P., Newman S., Beckie A., Clelland S., Hayden K. A. and Beausejour P. (2003), Performance Measurement Systems in Health and Mental Health Services: Models, Practices and Effectiveness, The Alberta Heritage Foundation for Medical Research.

AICPA (2001), Performance Measurement Practices Survey Results, AICPA, New York, NY.

Allard, M. (1998), "Overcoming cultural barriers to the adoption of object technology", Information Systems Management, Vol. 15 No. 3, pp. 82-5.

Anon (2000), The Oliver Wight $A B C D$ Check List $-5^{\text {th }}$ Edition, John Wiley \& Sons, Inc, New York

Avison, D.E. and Myers, M.D. (1995), "Information systems and anthropology: an anthropological perspective on IT and organisational culture", Information Technology \& People, Vol. 8, No. 3, pp. 43-56

Baskerville R. (2003), "Hofstede never studied culture", Accounting, organizations and Society, Vol. 28, pp. 1-14

Bititci U. S., Carrie A. S., McDevitt L G, (1997), Integrated Performance Measurement Systems: A Development Guide, International Journal of Operations and Production Management, Vol. 17, No. 6, MCB University Press, pp. 522-535.

Boland, R., Tenkasi, R. and Te'eni, D. (1994), “'Designing information technology to support distributed cognition”, Organization Science, Vol. 5, No. 3, pp. 456-75. 
Bourne M. and Neely A., (2000), "Why performance measurement interventions succeed and fail", Proceedings of the $2^{\text {nd }}$ International Conference on Performance Measurement, Cambridge UK, pp. 165-173.

Bourne M., (2001), "Implementation Issues", Hand Book of Performance Measurement, GEE Publishing Ltd., 100 Avenue Road, Swiss Cottage, London, NW3 3PG.

Bourne M., Mills J., Wilcox M., Neely A. and Platts K. (2000), "Designing, implementing and updating performance measurement systems", International Journal of Operations and Production Management, Vol. 20, Issue. 7, pp. 754-771.

Bourne, M., Neely, A., Platts, K., Mills, J. (2002) "The success and failure of performance measurement initiatives", International Journal of Operations \& Production Management, Vol. 22, No. 11, pp. 1288-1310

Braam, G.J.M. and Nijssen, E.J. (2004). Performance effects of using the balanced scorecard: a note on the Dutch experience, Long Range Planning, 37 : 335-349.

Brown, A.D. and Starkey, K. (1994), 'The effect of organisational culture on communication and information", Journal of Management Studies, Vol. 31, No. 6, pp. $807-28$

Burnes, B., Cooper, C. and West, P. (2003), "Organisational learning: the new management paradigm?", Management Decision, Vol. 41, No. 5, pp. 452-464.

Cameron K S, Quinn R E. (1999), Diagnosing and Changing Organisational Culture: Based on the Competing Values Framework, Addison-wesley Inc., Reading, US.

Chenhall R. H. (2003), "Management control systems design within its organisational context: findings from contingency-based research and directions for the future", Accounting, Organizations and Society 28 (2003) pp. $127-168$ 
Claver E., Llopis J., Gonzàlez R., Gascò J. L. (2001), "The performance of information system through organization culture", Information Technology and People, Vol. 14, No. 3, pp. 247-260

Collins J. C., Porras J.I. (1994), Built to last - Successful Habit of Visionary Companies. Haper Business, New York

Cross K.F. and Lynch R. L, (1988 -1989), "The SMART way to define and sustain success", National Productivity Review, Vol. 9, No 1, 1988-1989.

Daily, B., Whatley, A., Ash, S.R. and Steiner, R.L. (1996), “'The effects of a group decision support system on culturally diverse and culturally homogeneous group decision making", Information \& Management, Vol. 30 No. 6, pp. 281-9.

Davis S. and Albright T, (2004), An investigation of the effect of Balanced Scorecard implementation in financial performance, Management Accounting Research 15(2), 135-153.

Denison, D.R. (1990), Corporate Culture and Organisational Effectiveness, Wiley, New York, NY.

Dettmer H.W., (1997), "Goldratt's Theory of Constraints: A Systems Approach to Continuous Improvement”, McGraw-Hill.

De Waal, A.A. (2002), "The role of behavioural factors in the successful implementation and use of performance management systems", in Neely A. D., Walters A., Austin R (eds), Performance Measurement and Management: Research and Action, Centre for Business Performance, Cranfield School of Management

Dixon JR, Nanni AJ, Vollmann TE, (1990), The new performance challenge: measuring operations for world class competition, Dow Jones -Irwin Homewood II, 1990 
Doumeingts G, Clave F and Ducq Y, (1995), ECOGRAl - A method for designing and implementing Performance Measurement Systems for industrial organisations, in Rolstadas A (ed) Benchmarking Theory and Practice, Chapman \& Hall, London 1995

Eccles R G, (1991), The performance measurement manifesto, Harvard Business Review, January 1991, 131-138.

Eden C and Huxham C, (1996), Action Researcher for Management Research, British Academy of Management, Vol 7, pp75-86.

Fitzgerald L., Johnston R., Brignall T. J., Silvestro R. and Voss C. (1991), Performance Measurement in Service Industries, CIMA, London.

Franco M, and Bourne M. (2003), "Factors that play a role in managing through measures", Management Decision, Vol. 41, No. 8, pp. pp. 698-710.

Goldratt E. M. and Cox J. (1986), "The Goal: A Process of Ongoing Improvement", North River Press, NY.

Gordon, G.G. and DiTomaso, N. (1992), "Predicting corporate performance from organisational culture", Journal of Management Studies, Vol. 29, pp. 783-98.

Gordon, S.R. and Gordon, J.R. (1992), "Organisational hurdles to distributed database management systems adoption", Information \& Management, Vol. 22 No. 6, pp. $335-45$

EFQM (1999), "Self- assessment Guidelines for Companies", European Foundation fro Quality of Management, Brussels, Belgium.

Handy, CB (1985), Understanding Organisations, Harmondsworth: Penguin Harkness 
Harrison G L. and McKinnon J L. (1999), "Cross-cultural research in management control systems design: a review of the current state", Accounting, Organizations and Society n. 24 pp. 483-506

Harrison R. (1987), Organization, culture and quality of service: a strategy for releasing love in the workplace, London: Association for Management Education and Development.

Hayes R. H. and Abernathy W. J. (1980), "Managing our way to economic decline", Harvard Business Review, July-August 1980, Pages 67-77.

Hibbard, J. (1998), “Cultural breakthrough”, InformationWeek, No. 701, pp. 44-55.

Ho, S. and McKay, R.B. (2002), "Balanced scorecard: two perspectives", The CPA Journal, Vol. 72 No. 3 , pp. 20-5

Hofstede, G. (1980), Culture's Consequences, Beverly Hill, CA: Sage

Hofstede, G. and Bond, M.H. (1988), "The Confucius connection: From cultural roots to economic growth," Organisational Dynamics, Vol. 16, No. 4, pp. 4 - 21

Holloway J. (2001), "Investigating the impact of performance measurement", Int. J. Business Performance Management, Vol. 3, Nos. 2/3/4. Pages 167-180.

Hoque Z. and James W., (2000), Linking balanced scorecard measures to size and market factors: impact on organisational performance, Journal of Management Accounting Research 12(1), 1-15.

Ittner D., Larcker D. F. and Randall T, (2003), Performance implications of strategic performance measurement in financial services firms, Accounting, Organisation and Society 28(7-8), 715-741.

Johnson H. T., Kaplan R. S. (1987), Relevance Lost - The Rise and Fall of Management accounting, Harvard Business School Press, Boston, MA. 
Johnson, P. and Gill, J. (1993), Management Control and Organisational Behaviour, P. Chapman, London.

Johnston, R., Brignall, S. and Fitzgerald, L. (2002), “'Good enough performance measurement: a trade-off between activity and action", Journal of the Operational Research Society, Vol. 53 No. 3, March, pp. 256-62.

Kaplan R. S. and Norton D. P. (1992), "The Balanced Scorecard - Measures That Drive Performance", Harvard Business Review, January-February 1992 issue.

Kaplan R. S. and Norton D. P. (2001), "Transforming the balanced scorecard from performance measurement to strategic management: Part II", Accounting Horizons, Vol. 15 No 2 pp. $147-60$

Kaplan R.S. and Norton D.P. (1996), Translating strategy into action: The balanced scorecard, Harvard Business School Press, Boston, Mass 1996.

Kaplan R S (1998), Innovative Action Research: Creating New Management Theory and Practice, Journal of Management Accounting Research, vol.10, pp89-118.

Kaplan R.S. and Norton D.P. (2001), The Strategy-Focused Organization: How Balanced Scorecard Companies Thrive in the New Business Environment, Harvard Business School Press, Boston, Mass 2001.

Katz, J.P. and Townsend, J.B. (2000), "The role of information technology in the fit between culture, business strategy and organisational structure of global firms", Journal of Global Information Management, Vol. 8 No. 2, pp. 24-35.

Keegan D. P., Eiler R. G. and Jones C. R. (1989), "Are your performance measures obsolete?", Management Accounting, June 1989, Pages 45-50.

Kennerley M. and Neely A. (2003), "Measuring performance in changing business environment", International Journal of Operations and Production Management, Vol. 23, No. 2, Pages 213-229. 
Kochhar A, Kennerley M and Davies A, (1996), Improving Your Business Through Effective Manufacturing Planning and Control, Workbook produced by researchers at UMIST as part of an EPSRC Funded research programme.

Krause O, (1999), "Performance Management", Global Production Management edited by Mertins K, Krause O and Schallock B, Kluwer Academic Publishers, ISBN 0-7923-8605-1

Lebas M. and Weigenstein J. (1986), "Management control: the roles of rules, markets and culture", Journal of management studies, Vol. 23, No. 3 pp. 259-272

Likert R. (1967), The human organization -Its management and value, New York, McGraw-Hill

Lingle, J.H. and Schiemann, W.A. (1996), “From Balanced Scorecard to strategic gauges: is measurement worth it?", Management Review, Vol. 85 No. 3, pp. 56-62

Lippitt, R. and White, K. (1958), An experimental study of leadership and group life in Macoby, E.E, Newcomb T.M., Hartley E.L., Reading in social Psychology, Holt, Rinehart \& Winston, New York.

Mooraj S., Oyon D. and Hostettler D. (1999) The balanced scorecard: a necessary good or an unnecessary evil?", European Management Journal, Vol. 17 No 5 pp. $481-489$

Neely A, Mills J., Platts K., Richards H., Gregory M. and Bourne M. (2000), "Performance measurement system design: developing and testing process a process-based approach", International Journal of Operations and Production Management, Vol. 20, No. 9-10, Pages 1119-1145.

Neely A. and Adams C. (2001), "The Performance Prism Perspective", Journal of Cost Management, January/February 2001. 
Neely A., Mills J., Gregory M. and Platts K. (1995), "Performance measurement system design - a literature review and research agenda", International Journal of Operations and Production Management, Vol.15, No.4, Pages 80-116.

Neely A., Mills J., Gregory M., Richards H., Platts K. and Bourne M. (1996), Getting the measure of your business, University of Cambridge, Manufacturing Engineering Group, Mill Lane, Cambridge.

Neely A., Kennerley M and Martinez V, (2004), Does the Balanced Scorecard Work: An Empirical Investigation, Performance Measurement Association Conference, July 2004, Edinburgh, UK.

Newman, V. and Chaharbaghi, K. (1998), "The corporate culture myth”, Long Range Planning, Vol. 31 No. 4, pp. 514-22.

Nudurupati S. S. (2003), Management and Business Implications of IT-supported Performance Measurement, PhD Thesis, University of Strathclyde, UK.

Oliver N, (1996), "Design and Development Benchmarking", $5^{\text {th }}$ Operations Strategy and Performance Measurement Workshop, Loughborough University, 8 May 1996.

Olson M. H. (1982), "New information technology and organisational culture", MIS Quarterly, Vol. 6, No. 5, pp. 9-42

O'Reilly, C.A. and Chatman, J.A. (1996), "Culture as social control: corporations, cults, and commitment", in Staw, B.M. and Cummings, L.L. (Eds), Research in Organisational Behaviour, Vol. 18, JAI Press, Greenwich, CT, pp. 175-200.

Pande P and Holpp L, (2004), "What is Six Sigma?", McGraw-Hill Education, London.

Peter S. P., Robert P. N. and Roland C., (2002), "The Six Sigma Way Team Fieldbook: An Implementation Guide for Project Improvement Teams" McGraw-Hill Publishing. 
Pheysey D C. (1993), Organisational Cultures. Types and Transformation, Routledge, London

Pliskin, N., Romm, T., Lee, A.S. and Weber, Y. (1993), "Presumed versus actual organisational culture: managerial implications for implementation of information systems", The Computer Journal, Vol. 36 No. 2, pp. 143-52

Quinn R.E. and McGrath, M. (1958), "The transformation of organisational cultures: a competing values perspective" in Frost, P.J., Moore, L. F., Louis, M. R., Lundberg C. C., Marin J. Organisational Culture, Praeger, New York.

Robey, D. and Azevedo, A. (1994), "Cultural analysis of the organisational consequences of information technology", Accounting, Management and Information Technology, Vol. 4 No. 1, pp. 23-37.

Schein E. H. (1985), Organisational culture and leadership, San Francisco, JosseyBass

Scott, T., Mannion, R., Marshall, M. and Davies, H. (2003), "Does organisational culture influence health care performance? A review of the evidence", Journal of Health Services Research and Policy, Vol. 8, No. 2, pp. 105-117.

Skinner W. (1974), "The decline, fall, and renewal of manufacturing", Industrial Engineering, October, Pages 32-38.

Suwingnjo P., Bititci U. S. and Carrie A. S., (1997), "Quantitative Models for Performance Measurement System: An Analytical Hierarchy Process Approach", Managing Enterprises - Stakeholders, Engineering, Logistics, and Achievement, Mechanical Engineering Publications Ltd., pp. 237-243.

The Conference Board (1999), Aligning Strategic Performance Measures and Results, Conference Board, New York, NY. 
Thompson, M., Wildavsky, A. (1986), "A cultural theory of information bias in organizations", Journal of Management Studies, Vol. 23, pp. 273-86

Tolsby, J. (1998), “Effects of organisational culture on a large scale IT introduction effort: a case study of the Norwegian army's EDBLE project", European Journal of Information Systems, Vol. 7 No. 2, 108-14.

Turner T. J., Bititci U. S., (1999), "Maintaining reliability of business processes using active monitoring techniques." International Journal of Business Performance Measurement, Vol. 1. No. 2, Pages 186-199.

Wang, C.L. and Ahmed, P.K. (2003), "Organisational learning: a critical review", The Learning Organization, Vol. 10, No. 1, pp. 8-17.

Womack J P and Jones D T (2003), Lean Thinking: Banish Waste and Create Wealth in Your Corporation, Free Press. 